Article

\title{
Economic Growth and Climate Change: A Cross-National Analysis of Territorial and Consumption-Based Carbon Emissions in High-Income Countries
}

\author{
Kyle W. Knight ${ }^{1, *}$ and Juliet B. Schor ${ }^{2}$
}

1 Department of Sociology, University of Alabama in Huntsville, 344H Morton Hall, 301 Sparkman Drive, Huntsville, AL 35899, USA

2 Department of Sociology, Boston College, 531 McGuinn Hall, 140 Commonwealth Avenue, Chestnut Hill, MA 02467, USA; E-Mail: juliet.schor@bc.edu

* Author to whom correspondence should be addressed; E-Mail: kyle.knight@uah.edu; Tel.: +1-256-824-2294; Fax: +1-256-824-2387.

Received: 26 April 2014; in revised form: 21 May 2014 / Accepted: 3 June 2014 /

Published: 10 June 2014

\begin{abstract}
An important question in the literature on climate change and sustainability is the relation between economic growth and greenhouse gas emissions. While the "green growth" paradigm dominates in the policy arena, a growing number of scholars in wealthy countries are questioning the feasibility of achieving required emissions reductions with continued economic growth. This paper explores the relationship between economic growth and carbon dioxide emissions over the period 1991-2008 with a balanced data set of 29 high-income countries. We present a variety of models, with particular attention to the difference between territorial emissions and consumption-based (or carbon footprint) emissions, which include the impact of international trade. The effect of economic growth is greater for consumption-based emissions than territorial emissions. We also find that over this period there is some evidence of decoupling between economic growth and territorial emissions, but no evidence of decoupling for consumption-based emissions.
\end{abstract}

Keywords: economic growth; climate change; decoupling 


\section{Introduction}

The United Nations Environment Programme defines a green economy as "one that results in improved human well-being and social equity, while significantly reducing environmental risks and ecological scarcities" [1] (p. 16). The most serious environmental risk facing the world today is global climate change. The most recent assessment of the Intergovernmental Panel on Climate Change reported $95 \%-100 \%$ confidence that most of the global warming in the last six decades has been caused by humans and that there is evidence of increased frequency and severity of extreme weather due to climate change [2]. The principal cause of climate change is emissions of greenhouse gases, especially carbon dioxide emissions resulting from the burning of fossil fuels [3]. As a result, an increasing number of scientists are calling for radical and rapid emissions cuts, first in the wealthy nations of the Global North [4,5]. The UNEP definition begs the question of whether it is possible to simultaneously improve human well-being via economic growth and reduce carbon emissions (and other ecological impacts). That is the question to which this paper is addressed. The possible incompatibility arises because there is strong evidence of a tight relation between GDP and $\mathrm{CO}_{2}$ emissions. According to a recent cross-national study by Steinberger et al., economic development is more strongly linked to emissions than it is to life expectancy, such that some countries are able to achieve high life expectancy with low emissions, but none are able to achieve low emissions with a high level of economic development [6].

The question of whether continued growth is feasible in light of the need for radical emissions reductions has become a topic of interest for social scientists in wealthy countries. Given limited "ecological space," [7] as well as an urgent need to reduce emissions rapidly, some scholars are arguing that wealthy countries must to aim for either a steady-state or even de-growth [4,8-11]. Their reasoning is that it will not be possible to achieve required emissions requirements while simultaneously increasing the size of the economy. By contrast, the dominant assumption in the global and most national policy discourses is that it is feasible to decouple economic growth from emissions, so that emissions targets can be achieved even while economies are expanding.

This article contributes to this debate as well as to the larger literature on climate change and sustainability by empirically assessing the effect of economic growth on carbon dioxide emissions using measures of both territorial (i.e., production-based) emissions and consumption-based (i.e., trade-adjusted) emissions. We also test whether any decoupling of economic growth from emissions is occurring over time.

\section{Literature Review}

On the basis of data at the national-level, numerous studies [12-14] have documented a strong, positive relationship between carbon dioxide emissions and economic development, or affluence. At the global level, Granados and Carpintero [15], found that when the global economic growth rate increases by one percentage point the growth rate of global carbon dioxide emissions rises by 1.2 percentage points.

While some scholars have argued for the existence of an environmental Kuznets curve, in which environmental impacts increase with economic development up to a certain level of development and then decline with further growth [16], most cross-national research finds that carbon emissions rise 
linearly with development [3]. However, Jorgenson and Clark [13] have found that the relationship between economic development (measured as GDP per capita) and total carbon dioxide emissions weakened slightly between 1960 and 2005 in developed (i.e., high-income) countries, providing some evidence of relative decoupling between the economy and emissions (occurring mainly since 1985). Evidence of a small degree of decoupling was also found for carbon intensity (i.e., emissions per GDP), but for per capita emissions the linkage to economic development intensified, briefly declined, and then remained stable between 1985 and 2005. Jorgenson and Clark also found that in less-developed countries the relationship between economic development and per capita emissions intensified over this period. Developed countries may have achieved their modest decoupling by transferring some carbon-intensive production to less-developed countries.

The present study aims to further this line of research by assessing the relationship between economic growth and emissions at the national-level using data for 29 high-income countries. We are particularly interested in the impact of growth on emissions, both to illustrate basic economic/emissions relations and also to see whether low or high growth periods are more or less conducive to the development of a "greener" economy [17,18]. High growth periods may yield more investment in low-carbon energy sources; however, they also yield higher impact as a result of high production. Similarly, slow growth periods usually result in reduced investment in new technologies. However, they may have an opposite impact and result in state investments in renewable energy as a component of macroeconomic stimulus, as well as lower impact due to lower production. For discussions of the impact of the 2009 recession and subsequent stimulus spending on the transition to renewable energy see Geels [17] and Schor [18].

Recent research has demonstrated the importance of distinguishing between territorial and consumption-based emissions. In most developed countries, consumption-based greenhouse gas emissions are found to be higher than territorial emissions [19]. Among OECD member nations, consumption-based carbon emissions were estimated to be about 5\% higher than territorial emissions in 1995 [20]. Peters and Hertwich [21] found that 21.5\% of global CO2 emissions in 2001 were embodied in international trade and that developed countries are typically net importers of emissions while developing countries are net exporters. Furthermore, Lamb et al. [22] uncovered differences in contributions to territorial and consumption-based emissions, with economic development and exports exhibiting more strongly significant effects on the latter in a cross-sectional regression analysis. Peters et al. [23] also found that in developed countries, consumption-based emissions grew faster than territorial emissions between 1990 and 2008, due largely to increasing imports from less-developed countries, among which territorial-based emissions have doubled.

With our brief study, we advance this line of research by using panel data to assess the effect of economic growth on emissions, and whether that relationship has intensified or decoupled over time, using data for consumption-based emissions as well as territorial emissions.

\section{Methods and Data}

Consistent with previous research, we employ the Prais-Winsten regression model with panel corrected standard errors [24] and correction for first-order autocorrelation and include dummy variables for each year to allow for period-specific intercepts [13]. This modeling strategy allows for disturbances that are heteroskedastic and contemporaneously correlated across panels. Including the 
dummy variables for each year allows us to control for period effects common to all countries. As noted below, for the decoupling analysis in Table 4 a linear measure of year is used instead of dummy variables for each year.

As a robustness check, we also estimate the models using pooled OLS regression with Driscoll-Kraay standard errors since it has been demonstrated that this method is more appropriate than the above method when the number of cross-sections is larger than the number of time periods [25]. The Driscoll-Kraay standard errors are heteroskedasticity- and autocorrelation-consistent and robust to general forms of cross-sectional and temporal dependence [25].

In order to address heterogeneity bias (arising from unmeasured time-invariant differences between countries) and non-stationarity, we first-difference each variable (except for the year variables). All variables, except year, were converted to natural logarithms before differencing; thus, the coefficient estimates can be interpreted as the percentage change in the dependent variable for a $1 \%$ increase in the independent variable, all else constant.

We estimate these models with a balanced dataset consisting of 29 high-income (i.e., developed) countries with annual data for 1991 to 2008. Consistent with previous research, we include in this category countries that were classified by the World Bank as "high income" in 2008 [13]. These countries are: Australia, Austria, Belgium, Canada, Cyprus, Czech Republic, Denmark, Finland, France, Germany, Greece, Hungary, Italy, Japan, South Korea, Luxembourg, Malta, Netherlands, New Zealand, Norway, Portugal, Singapore, Slovakia, Slovenia, Spain, Sweden, Switzerland, United Kingdom, and the United States. The overall sample size is $\mathrm{N}=522$. Descriptive statistics and the correlation matrix for all variables are presented in Tables 1 and 2, respectively.

Table 1. Descriptive statistics.

\begin{tabular}{lcc}
\hline Variable & Mean & Standard Deviation \\
\hline Territorial emissions & -0.001 & 0.069 \\
Consumption-based emissions & 0.003 & 0.081 \\
GDP per capita & 0.021 & 0.027 \\
Exports \% GDP & 0.021 & 0.071 \\
Imports \%GDP & 0.020 & 0.065 \\
Urban \% Population & 0.003 & 0.004 \\
Year & 9.5 & 5.19 \\
\hline 522. All variables except year were first-differenced after converting to natural log form.
\end{tabular}

Table 2. Correlation matrix.

\begin{tabular}{lcccccc}
\hline Variable & $\mathbf{1}$ & $\mathbf{2}$ & $\mathbf{3}$ & $\mathbf{4}$ & $\mathbf{5}$ & $\mathbf{6}$ \\
\hline Territorial emissions & & & & & & \\
Consumption-based emissions & 0.456 & & & & & \\
GDP per capita & 0.176 & 0.310 & & & & \\
Exports \% GDP & -0.125 & -0.131 & -0.082 & & & \\
Imports \% GDP & -0.078 & 0.048 & 0.091 & 0.736 & & \\
Urban \% Population & 0.071 & 0.051 & -0.005 & -0.046 & -0.041 & \\
Year & -0.040 & 0.090 & 0.137 & 0.020 & 0.117 & 0.032 \\
\hline
\end{tabular}

$\mathrm{N}=522$. All variables except year were first-differenced after converting to natural log form. 


\subsection{Dependent Variables}

In order to assess the effects of economic growth on emissions, we focus on two dependent variables: (1) per capita territorial carbon dioxide emissions and (2) per capita consumption-based carbon dioxide emissions.

The territorial measure only captures emissions that occur within a country, thereby including emissions embodied in exports, and excluding emissions embodied in imports. An alternative strategy for the accounting of emissions is a consumption-based measure, which includes emissions from domestic activities and emissions embodied in imports and subtracts emissions embodied in exports. The latter measure is increasingly important in a global economy, in which production and consumption activities are spatially separated.

The territorial emissions data include emissions from the combustion of fossil fuels, cement production, and gas flaring, but exclude emissions from land use change. These data were calculated by Boden, Marland, and Andres [26] and were gathered from the dataset prepared and provided by Peters et al. [23]. The consumption-based emissions data were made available by Peters et al. [23], who calculated them by adjusting the territorial emissions data to account for emissions transfers via international trade. These data are available for 1990-2008, but the first year of data is lost when first-differencing. We calculated per capita values using population data from the World Bank [27].

\subsection{Independent Variables}

The main independent variable in our analysis is per capita gross domestic product (GDP) measured in 2005 US\$. These data are from the World Bank [26]. In line with previous research [13], we also include controls for international trade (imports and exports as a percentage of GDP) and the percentage of population living in urban areas. Data for these variables are from the World Bank [27]. In the decoupling analysis, year $(1=1991 \ldots 18=2008)$ and the interaction between GDP per capita and year are also included in the models.

\section{Analysis and Results}

Table 2 demonstrates that there is a positive correlation between economic growth and both measures of emissions. Both correlations are statistically significant ( $p<0.001$, two-tailed test). However, the correlation is much higher for consumption-based emissions $(0.310)$ than for territorial emissions (0.176).

Table 3 presents results for the Prais-Winsten (PCSE) and Driscoll-Kraay (DK) models estimating the effect of economic growth on carbon emissions. While the magnitude of the coefficients estimated by these two methods vary somewhat, the results are consistent with regards to direction and significance. Models 1 and 2 were estimated without control variables. We find that in all cases, there is a large and significant positive effect of economic growth on carbon dioxide emissions. In Model 1, the coefficient for economic growth is positive and significant $(p<0.01)$ for both the Prais-Winsten $(b=0.667)$ and Driscoll-Kraay estimations $(b=0.648)$. In Model 2 , the dependent variable is consumption-based emissions and compared to Model 1 the coefficient for economic growth is much larger in magnitude in both the Prais-Winsten $(b=0.997)$ and Driscoll-Kraay estimations $(b=1.067)$. 
Furthermore, we observe that $R^{2}$ is consistently and substantially higher when predicting consumption-based emissions, which suggests that economic growth explains greater variation in consumption-based emission than in territorial emissions. These findings are in line with our expectations for high-income countries, which have outsourced carbon-intensive production to less-developed countries, and are re-importing the $\mathrm{CO}_{2}$ via imports.

Table 3. Unstandardized coefficients for the regression of per capita territorial and consumption-based carbon dioxide emissions: first-difference model estimates.

\begin{tabular}{|c|c|c|c|c|c|c|c|c|}
\hline & \multicolumn{2}{|c|}{ Model 1} & \multicolumn{2}{|c|}{ Model 2} & \multicolumn{2}{|c|}{ Model 3} & \multicolumn{2}{|c|}{ Model 4} \\
\hline Emission & \multicolumn{2}{|c|}{ Territorial } & \multicolumn{2}{|c|}{ Consumption } & \multicolumn{2}{|c|}{ Territorial } & \multicolumn{2}{|c|}{ Consumption } \\
\hline Method & PCSE & DK & PCSE & DK & PCSE & DK & PCSE & DK \\
\hline GDP p.c. & $\begin{array}{l}0.667 * * \\
(0.128)\end{array}$ & $\begin{array}{l}0.648 * * \\
(0.106)\end{array}$ & $\begin{array}{l}0.997 * * \\
(0.176)\end{array}$ & $\begin{array}{l}1.067 * * \\
(0.291)\end{array}$ & $\begin{array}{l}0.643 * * \\
(0.131)\end{array}$ & $\begin{array}{l}0.608 * * \\
(0.098)\end{array}$ & $\begin{array}{l}0.879 * * \\
(0.175)\end{array}$ & $\begin{array}{l}0.924 * * \\
(0.239)\end{array}$ \\
\hline $\begin{array}{l}\text { Exports } \\
\% \text { GDP }\end{array}$ & & & & & $\begin{array}{r}-0.026 \\
(0.062)\end{array}$ & $\begin{array}{l}-0.053 \\
(0.057)\end{array}$ & $\begin{array}{l}-0.258 * * \\
(0.063)\end{array}$ & $\begin{array}{l}-0.286 * * \\
(0.070)\end{array}$ \\
\hline $\begin{array}{l}\text { Imports } \\
\% \text { GDP }\end{array}$ & & & & & $\begin{array}{r}-0.022 \\
(0.074) \\
\end{array}$ & $\begin{array}{l}-0.010 \\
(0.051)\end{array}$ & $\begin{array}{l}0.220 * * \\
(0.080)\end{array}$ & $\begin{array}{l}0.266 * * \\
(0.078)\end{array}$ \\
\hline Urban \% & & & & & $\begin{array}{l}1.258 * \\
(0.515)\end{array}$ & $\begin{array}{l}1.199 * \\
(0.463)\end{array}$ & $\begin{array}{l}0.993{ }^{\dagger} \\
(0.531)\end{array}$ & $\begin{array}{l}0.897 * \\
(0.468)\end{array}$ \\
\hline Intercept & 0.014 & 0.014 & 0.012 & 0.013 & 0.011 & 0.011 & 0.013 & 0.015 \\
\hline$R^{2}$ & 0.1282 & 0.1044 & 0.1895 & 0.1678 & 0.1372 & 0.1116 & 0.2194 & 0.1970 \\
\hline $\begin{array}{l}\dagger p<0 \\
\text { control } \\
\text { conver } \\
\text { DK ref }\end{array}$ & $\begin{array}{l}0 * p<0 \\
\text { or perio } \\
\mathrm{g} \text { to natu }\end{array}$ & $\begin{array}{l}* * p<0 \\
\text { ffects. Al } \\
\log \text { form. I }\end{array}$ & $\begin{array}{l}\text { (two-taile } \\
\text { ariables } \\
\text { E refers to }\end{array}$ & $\begin{array}{l}\text { sts). } \mathrm{N}= \\
\text { pt the } \\
\text { rais-Win }\end{array}$ & $\begin{array}{l}\text { All mo } \\
\text { dummy- } \\
\text { egressio }\end{array}$ & $\begin{array}{l}\text { include } \\
\text { tbles wer } \\
\text { th panel- }\end{array}$ & $\begin{array}{l}\text { dummy-var } \\
\text { rst-differenc } \\
\text { cted standa }\end{array}$ & $\begin{array}{l}\text { ables to } \\
\text { d after } \\
\text { errors. }\end{array}$ \\
\hline
\end{tabular}

In Models 3 and 4, which include the control variables, the difference in coefficients is somewhat lower. For the Prais-Winsten estimates, the coefficient is $0.643(p<0.01)$ when predicting territorial emissions and $0.879(p<0.01)$ when predicting consumption-based emissions. For the Driscoll-Kraay estimates, the coefficient is $0.608(p<0.01)$ when predicting territorial emissions and $0.924(p<0.01)$ when predicting consumption-based emissions. Urban (\% population) is positive and significant in all models in which it was included. As expected, when predicting consumption-based emissions, but not territorial, exports (\% GDP) is significant and negative and imports (\% GDP) is significant and positive.

Using the statistical significance test proposed by Pasternoster et al. [28], the coefficient for economic growth was found to be significantly greater in Model 2 relative to Model 1 (for both estimation techniques), but only at the 0.10 level (upper-tailed test). The differences in the coefficients for economic growth observed between Models 3 and 4 were not found to be statistically significant, likely because these models control for imports and exports.

Overall, the results in Table 3 confirm that economic growth is indeed strongly linked to rising carbon emissions. Furthermore, these results provide some evidence that the relationship is stronger for consumption-based emissions than for territorial emissions.

To determine whether the relationship between economic growth and emissions has decoupled between 1991 and 2008, we estimate models with an interaction effect between economic growth and 
year, the results of which are presented in Table 4. We follow Brady et al. [29] in estimating an interaction effect between the key independent variable (GDP per capita) and year, which allows for the coefficient to vary over time. A negative and statistically significant coefficient for the interaction term is interpreted as evidence of decoupling over time (i.e., a diminishing effect of economic growth), while a significant positive interaction effect is interpreted as evidence of intensification (i.e., an increasing effect of economic growth). A non-significant coefficient would indicate a temporally stable relationship.

Models 1 and 2 (in Table 4) estimate the interaction effect on territorial and consumption-based emission growth rates, respectively, without the control variables. The interaction effect is significant and negative only in Model 1 (for both Prais-Winsten and Driscoll-Kraay estimates), supporting the interpretation of the outsourcing of emissions to lower-income trading partners. Models 3 and 4 include the control variables. In Model 4 (predicting consumption-based emissions), the interaction term remains non-significant (for both estimation techniques). In Model 3 (predicting territorial emissions), the interaction is negative and significant $(p<0.01)$ for the Driscoll-Kraay estimates and negative and nearly significant $(p=0.106)$ for the Prais-Winsten estimates. The results in Table 4 provide evidence for the hypothesis that decoupling between economic growth and carbon dioxide emissions has occurred between 1991 and 2008, but only for territorial emissions.

Table 4. Decoupling analysis: unstandardized coefficients for the regression of per capita territorial and consumption-based carbon dioxide emissions.

\begin{tabular}{|c|c|c|c|c|c|c|c|c|}
\hline \multirow{3}{*}{$\begin{array}{c}\text { Emission } \\
\text { Measure }\end{array}$} & \multicolumn{2}{|c|}{ Model 1} & \multicolumn{2}{|c|}{ Model 2} & \multicolumn{2}{|c|}{ Model 3} & \multicolumn{2}{|c|}{ Model 4} \\
\hline & \multicolumn{2}{|c|}{ Territorial } & \multicolumn{2}{|c|}{ Consumption } & \multicolumn{2}{|c|}{ Territorial } & \multicolumn{2}{|c|}{ Consumption } \\
\hline & PCSE & DK & PCSE & DK & PCSE & DK & PCSE & DK \\
\hline GDP p.c. & $\begin{array}{c}0.811 * * \\
(0.185)\end{array}$ & $\begin{array}{c}0.756 * * \\
(0.054)\end{array}$ & $\begin{array}{c}0.936 * * \\
(0.272)\end{array}$ & $\begin{array}{l}0.944 * \\
(0.374)\end{array}$ & $\begin{array}{c}0.730 * * \\
(0.189)\end{array}$ & $\begin{array}{c}0.665 * * \\
(0.079)\end{array}$ & $\begin{array}{c}0.735 * * \\
(0.282)\end{array}$ & $\begin{array}{l}0.730^{\dagger} \\
(0.365)\end{array}$ \\
\hline Year & $\begin{array}{c}-0.0001 \\
(0.001) \\
\end{array}$ & $\begin{array}{c}-0.0002 \\
(0.001) \\
\end{array}$ & $\begin{array}{c}0.001 \\
(0.001) \\
\end{array}$ & $\begin{array}{c}0.001 \\
(0.001) \\
\end{array}$ & $\begin{array}{c}-0.0002 \\
(0.001) \\
\end{array}$ & $\begin{array}{c}-0.0003 \\
(0.001) \\
\end{array}$ & $\begin{array}{c}0.001 \\
(0.001) \\
\end{array}$ & $\begin{array}{l}0.0003 \\
(0.001) \\
\end{array}$ \\
\hline $\begin{array}{c}\text { GDP p.c. } \\
* \text { Year }\end{array}$ & $\begin{array}{c}-0.046 * \\
(0.021) \\
\end{array}$ & $\begin{array}{c}-0.042 * * \\
(0.011)\end{array}$ & $\begin{array}{l}-0.011 \\
(0.029) \\
\end{array}$ & $\begin{array}{r}-0.003 \\
(0.037) \\
\end{array}$ & $\begin{array}{l}-0.034 \\
(0.021) \\
\end{array}$ & $\begin{array}{c}-0.031 * * \\
(0.010) \\
\end{array}$ & $\begin{array}{r}0.005 \\
(0.029) \\
\end{array}$ & $\begin{array}{c}0.011 \\
(0.035) \\
\end{array}$ \\
\hline $\begin{array}{l}\text { Exports } \\
\% \text { GDP }\end{array}$ & & & & & $\begin{array}{l}-0.052 \\
(0.062) \\
\end{array}$ & $\begin{array}{r}-0.083 \\
(0.060) \\
\end{array}$ & $\begin{array}{c}-0.284 * * \\
(0.065) \\
\end{array}$ & $\begin{array}{c}-0.310 * * \\
(0.073)\end{array}$ \\
\hline $\begin{array}{l}\text { Imports } \\
\% \text { GDP }\end{array}$ & & & & & $\begin{array}{l}-0.037 \\
(0.071)\end{array}$ & $\begin{array}{l}-0.015 \\
(0.047) \\
\end{array}$ & $\begin{array}{c}0.217 * * \\
(0.079)\end{array}$ & $\begin{array}{c}0.273 * * \\
(0.084)\end{array}$ \\
\hline Urban \% & & & & & $\begin{array}{l}1.083 * \\
(0.544)\end{array}$ & $\begin{array}{l}1.046^{\dagger} \\
(0.602)\end{array}$ & $\begin{array}{l}1.167 * \\
(0.544)\end{array}$ & $\begin{array}{l}1.146^{\dagger} \\
(0.579)\end{array}$ \\
\hline Intercept & -0.007 & -0.006 & -0.024 & -0.023 & -0.008 & -0.006 & -0.020 & -0.019 \\
\hline$R^{2}$ & 0.0607 & 0.0439 & 0.1121 & 0.0985 & 0.0745 & 0.0562 & 0.1479 & 0.1334 \\
\hline
\end{tabular}

Overall, our results yield three conclusions. First, economic growth has a consistent, positive and significant relationship with both territorial and consumption-based carbon dioxide emissions. Second, 
we find some evidence that economic growth has a stronger effect on consumption-based emissions than territorial emissions. Third, our results suggest that economic growth has to some degree decoupled from territorial emissions, but not from consumption-based emissions.

\section{Discussion and Conclusion}

The need for timely radical reductions in greenhouse gas emissions is increasingly recognized by scientists and policymakers. However, the dominant approach has been to remain squarely within the realm of "business-as-usual" economics, namely solutions that rely on technological shifts on the supply side, and voluntary behavior change on the household side. The hope is that economies can follow a path of "green growth," in which countries simultaneously achieve significant reductions in greenhouse gas emissions and increases in GDP. If past performance is relevant for future outcomes, our results, along with numerous other studies of the economy/emissions relationship, cast doubt on this approach $[3,14,15,30]$. While we find some reduction in the linkage between economic growth and territorial emissions, once we account for high-income countries' offshoring of emissions, there is no evidence of decoupling. Any given increase in GDP elicits no less increase in $\mathrm{CO}_{2}$ than in the past. Optimistic projections of decoupling are not borne out in the history of the two decades between 1991 and 2008. Furthermore, we find that higher growth rates yield higher emissions.

The continuing policy emphasis on raising the rate of economic growth that characterizes many governments should be re-thought in light of its demonstrated incompatibility with required radical emissions reductions. Technological and voluntary solutions alone will not be sufficient; High-income countries also need to address aggregate demand in order to achieve the kinds of radical emissions cuts that are required to avoid catastrophic climate change [4,5].

Given this context, it has become more important for developed countries to maintain and improve social well-being (e.g., health, employment, etc.) without continual increases in the scale of the economy, by, for example, reducing work hours [31]. The importance of this line of thought is highlighted by Jorgenson's [32] recent study demonstrating that in the combined region of North America, Europe, and Oceania (comprising mostly developed countries), economic development is associated with a rising carbon intensity of well-being, meaning that at higher levels of development it takes greater emissions to increase human well-being, measured as life expectancy.

Our findings also suggest that both policymakers and researchers should pay more attention to different measures of carbon emissions. To date, the global policy regime has focused mainly on territorial emissions. However, the ability to offshore carbon emissions presents a potential loophole through which high-income countries can avoid full responsibility for their emissions. It is important for the global community to develop verifiable measures of consumption-based emissions and to consider them in future discussions [33]. To that end, research must concentrate more on consumption-based emissions, their relation to territorial emissions, and the dynamics that drive both measures. We offer this paper as a step in that direction.

\section{Author Contributions}

Both authors conceived of the study and wrote the paper. Kyle Knight performed the research and analyzed the data. 


\section{Conflicts of Interest}

The authors declare no conflicts of interest.

\section{References}

1. United Nations Environment Programme. Towards a Green Economy: Pathways to Sustainable Development and Poverty Eradication. Available online: http://www.unep.org/greeneconomy (accessed on 24 January 2014).

2. Intergovernmental Panel on Climate Change (IPCC). Summary for Policymakers. In Climate Change 2013: The Physical Science Basis; Contribution of Working Group I to the Fifth Assessment Report of the Intergovernmental Panel on Climate Change; Stocker, T.F., Qin, D., Plattner, G.K., Tignor, M., Allen, S.K., Boschung, J., Nauels, A., Xia, Y., Bex, V., Midgley, P.M., Eds.; Cambridge University Press: Cambridge, UK and New York, NY, USA, 2013.

3. Rosa, E.A.; Dietz, T. Human drivers of national greenhouse-gas emissions. Nat. Clim. Change 2012, 2, 581-586.

4. Anderson, K. Climate change going beyond dangerous-Brutal numbers and tenuous hope. Dev. Dialog. 2012, 61, 16-40.

5. Hansen, J.; Kharecha, P.; Sato, M.; Masson-Delmotte, V.; Ackerman, F.; Beerlin, D.J.; Hearty, P.J.; Hoegh-Guldberg, O.; Hsu, S.; Parmesan, C.; et al. Assessing "Dangerous climate change": Required reduction of carbon emissions to protect young people, future generations and nature. PLoS One 2013, 8, e81648.

6. Steinberger, J.K.; Roberts, J.T.; Peters, G.P.; Baiocchi, G. Pathways of human development and carbon emissions embodied in trade. Nat. Clim. Change 2012, 2, 81-85.

7. Sachs, W.; Loske, R.; Linz, M. Greening the North: A Post-Industrial Blueprint for Ecology and Equity; Zed Books: London, UK, 1998.

8. Latouche, S. Farewell to Growth; Polity: Cambridge, UK, 2009.

9. Martinez-Alier, J. Socially sustainable economic de-growth. Dev. Change 2009, 40, 1099-1119.

10. Victor, P.A. Managing without Growth: Slower by Design, Not Disaster; Edward Elgar: Cheltenham, UK, 2008.

11. Jackson, T. Prosperity without Growth: Economics for a Finite Planet; Earthscan: New York, NY, USA, 2009.

12. Dietz, T.; Rosa, E.A. Effects of population and affluence on $\mathrm{CO}_{2}$ emissions. Proc. Natl. Acad. Sci. USA 1997, 94, 175-179.

13. Jorgenson, A.K.; Clark, B. Are the economy and the environment decoupling? A comparative international study, 1960-2005. Am. J. Sociol. 2012, 118, 1-44.

14. York, R.; Rosa, E.A.; Dietz, T. A rift in modernity? Assessing the anthropogenic sources of global climate change with the STIRPAT model. Int. J. Sociol. Soc. Pol. 2003, 23, 31-51.

15. Granados, J.A.T.; Carpintero, O. Dispelling the smoke: $\mathrm{CO}_{2}$ emisisons and economic growth from a global perspective. Working Paper, University of Michigan. 2009. Available online: $\mathrm{http} / / /$ sitemaker.umich.edu/tapia_granados/files/co2_emissions_and_gdp_growth_-_dec_2009_-_f2.pdf (accessed on 25 October 2013). 
16. Grossman, G.M.; Krueger, A.B. Economic growth and the environment. Q. J. Econ. 1995, 110, 353-377.

17. Geels, F. The impact of the financial-Economic crisis on sustainability transitions: Financial investment, governance and public discourse. Environ. Innovat. Soc. Transit. 2013, 6, 67-95.

18. Schor, J.B. Sustainability transitions and economic downturns: The case of the US, 2008-2013. Environ. Innovat. Soc. Transit. 2014, in press.

19. Witting, H.C.; Vringer, K. Carbon and land use accounting from a producer's and consumer's perspective-An empirical examination covering the world. Econ. Syst. Res. 2009, 21, 291-310.

20. Ahmad, N.; Wyckoff, A. Carbon dioxide emissions embodied in international trade of goods. OECD Sci. 2003. Available online: http://www.oecd-ilibrary.org/science-and-technology/carbon-dioxideemissions-embodied-in-international-trade-of-goods_421482436815 (accessed on 13 June 2011).

21. Peters, G.P.; Hertwich, E.G. $\mathrm{CO}_{2}$ embodied in international trade with implications for global climate change. Environ. Sci. Tech. 2008, 42, 1401-1407.

22. Lamb, W.F.; Steinberger, J.K.; Bows-Larkin, A.; Peters, G.P.; Roberts, J.T.; Wood, F.R. Transitions in pathways of human development and carbon emissions. Environ. Res. Lett. 2014, 9, Article 014011.

23. Peters, G.P.; Minx, J.C.; Weber, C.L.; Edenhofer, O. Growth in emission transfers via international trade from 1990 to 2008. Proc. Natl. Acad. Sci. USA 2011, 108, 8903-8908.

24. Beck, N.; Katz, J.N. What to do (and not to do) with time-series cross-section data. Am. Polit. Sci. Rev. 1995, 89, 634-647.

25. Hoechle, D. Robust standard errors for panel regressions with cross-sectional dependence. Stata J. 2007, 7, 281-312.

26. Boden T.A.; Marland, G.; Andres, R.J. Global, Regional, and National Fossil-Fuel $\mathrm{CO}_{2}$ Emissions in Trends; Carbon Dioxide Information Analysis Center, Oak Ridge National Laboratory, U.S. Department of Energy: Oak Ridge, TN, USA, 2009.

27. World Bank. World Data Bank. Available online: http://databank.worldbank.org/ (accessed on 1 November 2013)

28. Paternoster, R.; Brame, R.; Mazerolle, P.; Piquero, A. Using the correct statistical test for the equality of regression coefficients. Criminology 1998, 36, 859-866.

29. Brady, D.; Kaya, Y.; Beckfield, J. Reassessing the effect of economic growth on well-being in less-developed countries, 1980-2003. Stud. Comp. Int. Dev. 2007, 42, 1-35.

30. Wagner, M. The carbon Kuznets curve: A cloudy picture emitted by bad econometrics? Resour. Energ. Econ. 2008, 30, 388-408

31. Knight, K.W.; Rosa, E.A.; Schor, J.B. Could working less reduce pressures on the environment? A cross-national panel analysis of OECD countries, 1970-2007. Globle Environ. Change 2013, 23, 691-700.

32. Jorgenson, A.K. Economic development and the carbon intensity of human well-being. Nat. Clim. Change 2014, 4, 186-189.

33. Andrew, R.M.; Davis, S.J.; Peters, G.P. Climate policy and dependence on traded carbon. Environ. Res. Lett. 2013, 8, Article 034011.

(C) 2014 by the authors; licensee MDPI, Basel, Switzerland. This article is an open access article distributed under the terms and conditions of the Creative Commons Attribution license (http://creativecommons.org/licenses/by/3.0/). 